\title{
Influence of foliar application with putrescine, salicylic, and ascorbic acid on the productivity and physical and chemical fruit properties of Picual olive trees
}

\author{
Laila F. Hagagg ${ }^{1}$, Nazmy Abd-Alhamid ${ }^{2}$, Hassan S. A. Hassan ${ }^{1}$, Ahmed M. Hassan ${ }^{1}$ and Esmail A. E. Geanidy ${ }^{1 *}$ (D)
}

\begin{abstract}
Background and objective: Olive tree is very popular in the Mediterranean area because of its fruits and oil yields. Both of them are worldwide known by their beneficial health properties. Salicylic acid is naturally occurring as phenolic compound and endogenously synthesized as signaling molecule in plants and influences various physiological and biochemical functions in plants. Ascorbic acid is an antioxidant molecule and a key substrate for the detoxification of ROS. Putrescine participates in several processes of plant growth and development. Putrescine participates in several processes of plant growth and development. Therefore, the objective of this study is to determine the best concentrations of these substances to improve olive fruits yield and its chemical and physical properties.
\end{abstract}

Materials and methods: The field experiment was conducted during two seasons of 2017 and 2018 on adult olive trees of Picual cv. (8 years old) in a private orchard located in Ismailia Governorate, Egypt, to study the effect of foliar application with different concentrations of putrescine, salicylic, and ascorbic, in two dates of November and December. The effect of different concentrations and dates of spray under the conditions of the saline irrigation water $\left(4.40 \mathrm{ds} \mathrm{m}^{-1}\right)$ were evaluated on the fruit yield, fruit physical characteristics and fruit chemical properties of olive trees of Picual cV.

Results: In this study, all treatments were able to improve all studied characters compared with the control treatment in both spraying dates of November and December in both seasons, respectively. Moreover, the best yield of olive fruits in this study was recorded with the application of putrescine at 15 ppm + salicylic at 200 ppm + ascorbic at 2000 ppm in the first and second seasons, respectively.

Conclusion: Spraying Picual olive trees with putrescine, salicylic, and ascorbic acid in this study under the conditions of the saline irrigation water $\left(4.40 \mathrm{ds} \mathrm{m}^{-1}\right)$ was able to improve fruit yield and fruit physical and chemical properties of olive trees of Picual cv. compared with the control treatment in both spraying dates

Keywords: Olive trees, Picual, Putrescine, Salicylice acid, Ascorbic acid, Productivity, Physical properties, Chemical properties

\footnotetext{
*Correspondence: esmail_nrc@yahoo.com

${ }^{1}$ Pomology Department, National Research Centre, 33 El Bohouth St, Cairo

12622, Egypt

Full list of author information is available at the end of the article
}

\section{Springer Open}

(c) The Author(s). 2020 Open Access This article is licensed under a Creative Commons Attribution 4.0 International License, which permits use, sharing, adaptation, distribution and reproduction in any medium or format, as long as you give appropriate credit to the original author(s) and the source, provide a link to the Creative Commons licence, and indicate if changes were made. The images or other third party material in this article are included in the article's Creative Commons licence, unless indicated otherwise in a credit line to the material. If material is not included in the article's Creative Commons licence and your intended use is not permitted by statutory regulation or exceeds the permitted use, you will need to obtain permission directly from the copyright holder. To view a copy of this licence, visit http://creativecommons.org/licenses/by/4.0/. 


\section{Introduction}

Oleaceae family includes 30 genera of deciduous trees and shrubs including olive tree and its relatives numbering about 600 species (Grohmann 1981; Atta-urRahman 1990). Oleaceae is best grown in Asia and Malaysia especially tropical and temperate regions of Asia (Pérez et al. 2005). The genus Olea comprises 30 species (Bracci et al. 2011), but Olea europaea L. is the most popular member of the genus Olea (Kaniewski et al. 2012). It is the only species of this genus which is used as food and is found in the Mediterranean region (Zohary et al. 2012; Sarwar 2013). The olive tree is a traditional symbol of abundance, glory, and peace, and its leafy branches were historically used to crown the victorious in friendly games. The olive fruit, oil, and the leaves of the tree have a rich history of nutritional, medicinal, and ceremonial uses (Soni et al. 2006). Olive tree is very popular in the Mediterranean area because of its fruits and oil. Both of them are worldwide known for their beneficial health properties (Kiritsakis 1998). Olive oil is produced at a level of around 2.6 million tonnes. It has a long history going back to pre-biblical times. It is produced and consumed mainly in Mediterranean countries, but demand is increasing in other countries in Northern Europe and in the USA as a consequence of strong marketing of this oil. Olive oil is considered to be an essential ingredient of the healthy Mediterranean lifestyle (Gunstone 2002).

Salicylic acid is naturally occurring as phenolic compound and endogenously synthesized as signaling molecule in plants and influences various physiological and biochemical functions in plants. It can act as an important signaling and competing various biotic and abiotic stresses. So it increases drought stress tolerance and salt stress tolerance (Arfan et al. 2007; Khan et al. 2015). Salicylic acid regulates important plant physiological processes such as nitrogen metabolism, photosynthesis, antioxidant defense system, proline metabolism, and plant-water relations, with concomitant protection in plants against abiotic stresses (Khan et al. 2012).

Ascorbic acid is an antioxidant molecule and a key substrate for the detoxification of reactive oxygen species (Foyer and Noctor 2011). Physiologically active form of ascorbic acid is the resonance stabilized anionic form, which is termed as ascorbate. Exogenous application of ascorbic acid can protect lipids and proteins against drought-induced oxidative adversaries (Naz et al. 2016). Ascorbic acid could improve tolerance against abiotic stresses by enhancing plant growth, rate of photosynthesis and photosynthetic pigments, transpiration, and oxidative defense potential. It is reported that ascorbic acid can effectively regulate anti-oxidative metabolism in plants (Noctor et al. 2014). Also, endogenous As levels could be improved by exogenous application of ascorbic acid (Athar et al. 2008).

Putrescine is one of the polyamines that are considered growth substances. Putrescine participates in several processes of plant growth and development, and its role as anti-senescence and anti-stress agent is previously reported by Ahmed et al. (2017). It works as an antioxidant and improves cell membrane stability ( $\mathrm{Li}$ et al. 2015). It plays a role in modulating the defense response of plants to varied environmental stresses including drought stress (Ahmed et al. 2013; Khorshidi and Hamedi 2014).

\section{Material and methods}

This study was carried out during two successive seasons (2017 and 2018) at a private orchard located at CairoIsmailia Desert Road (about $80 \mathrm{~km}$ from Cairo), Ismailia Governorate, Egypt. The study was conducted on 8 years old olive trees of Picual cv., planted at $4 \times 6 \mathrm{~m}$ apart grown in sandy soil, under drip irrigation system. The selected trees were uniformed in shape and received the common horticultural practices. The orchard soil analysis is given in Table 1, and the water irrigation analysis is given in Table 2 according to procedures which are outlined by Wild et al. (1985).

This experiment was designed to study the effect of spraying Picual olive trees with putrescine, salicylic acid, and ascorbic acid at different concentrations and dates, i.e., mid of November and mid of December (33 trees for each date) during two studied seasons as follows:

(Cont)-Control treatment (spray with distilled water only).

T1-Tree sprayed with putrescine (PUT) at $15 \mathrm{ppm}$.

T2-Tree sprayed with putrescine (PUT) at $30 \mathrm{ppm}$.

Table 1 Some physical and chemical properties of the orchard soil

Parameters Surface sample $30 \mathrm{~cm}$ depth $60 \mathrm{~cm}$ depth

Depth of simple (cm)

$\begin{array}{llll}\text { pH } & 8.02 & 8.70 & 8.11 \\ \text { EC(dSm-1) } & 3.80 & 0.80 & 1.70\end{array}$

Soluble cations (meq/l)

$\begin{array}{llll}\mathrm{Ca}^{++} & 6.00 & 2.50 & 3.00\end{array}$

$\begin{array}{llll}\mathbf{M g}^{++} & 4.00 & 1.50 & 1.50\end{array}$

$\begin{array}{llll}\mathrm{Na}^{+} & 28.60 & 4.40 & 12.90\end{array}$

$\begin{array}{llll}\mathbf{K}^{+} & 0.12 & 0.14 & 0.78\end{array}$

Soluble anions (meq/l)

$\mathrm{CO}_{3}^{-}$

$\begin{array}{llll}\mathrm{HCO}_{3}{ }^{-} & 4.40 & 2.40 & 2.00\end{array}$

$\begin{array}{llll}\mathrm{Cl}^{-} & 27.20 & 5.00 & 13.00\end{array}$

$\begin{array}{llll}\text { SO }_{4}= & 7.12 & 1.14 & 3.18\end{array}$ 
Table 2 Chemical characteristics of the used water well for the present study

\begin{tabular}{ll}
\hline Parameters & Values \\
\hline $\mathrm{pH}$ & 7.49 \\
$\mathrm{EC}\left(\mathrm{ds} \mathrm{m}{ }^{-1}\right.$ ) & 4.40 \\
Soluble cations (meq/l) & \\
$\mathrm{Ca}++$ & 7.50 \\
$\mathrm{Mg}++$ & 5.00 \\
$\mathrm{Na}+$ & 33.1 \\
$\mathrm{~K}+$ & 0.16 \\
$\mathrm{Soluble}^{+}$anions (meq/l) & \\
$\mathrm{CO}_{3}{ }^{-2}$ & - \\
$\mathrm{HCO}_{3}{ }^{-}$ & 1.60 \\
$\mathrm{Cl}^{-}$ & 40.00 \\
$\mathrm{SO}_{4}^{-2}$ & 4.16 \\
\hline
\end{tabular}

T3-Tree sprayed with salicylic acid (SAL) at 200 ppm.

T4-Tree sprayed with salicylic acid (SAL) at 300 ppm.

T5-Tree sprayed with ascorbic acid (ASC) at 2000 ppm.

T6-Tree sprayed with ascorbic acid (ASC) at 3000 ppm.

T7-Tree sprayed with putrescine at $15 \mathrm{ppm}+$ salicylic acid at $200 \mathrm{ppm}$.

T8-Tree sprayed with putrescine at $15 \mathrm{ppm}+$ ascorbic acid at $2000 \mathrm{ppm}$.

T9-Tree sprayed with salicylic acid at $200 \mathrm{ppm}+$ ascorbic acid at $2000 \mathrm{ppm}$.

T10-Tree sprayed with putrescine $15 \mathrm{ppm}+$ salicylic acid 200 ppm + ascorbic acid 2000 ppm.

Both groups of trees which were sprayed in November or December received other two spraying dates, i.e., the first at full bloom (during April) and the second after fruit set (during May). Each treatment was represented by three replicates (one tree per replicate) which were chosen randomly, and on early October of each season, twenty healthy 1-year old shoots well distributed around the canopy were randomly selected and labeled ( 5 shoots for each direction) for carrying out the following measurements:

Fruit yield ( $\mathrm{kg} /$ tree): Fruits were harvested at ripening stage on end of October in the years 2017 and 2018. Each individual tree was harvested manually, and weight of fruits/tree was measured. Average yield $(\mathrm{kg}) /$ tree was determined for each treatment.

Fruit physical characteristics: Thirty fruit per each tree were randomly selected for carrying out the fruit quality measurements:
1. Fruit weight (g): It was determined by weighing the samples (30 fruits) by ordinary balance with $0.01 \mathrm{~g}$ sensitivity, and average weight per fruit was calculated.

2. Pulp weight (g): It was determined by weighing the sample (30 fruits and their seeds), and average weight of pulp was calculated.

3. Pulp/seed ratio: Values were calculated by dividing the weight of the pulp over the weight of the seed.

4. Fruit length $(\mathrm{cm})$ : It was measured by digital caliper for the length of the sample (30 fruits), and the average weight of pulp was calculated.

5. Fruit diameter $(\mathrm{cm})$ : It was measured by a digital caliper for the diameter of the sample (30 fruits), and the average weight of pulp was calculated.

\section{Chemical properties of fruit \\ Flesh fruit oil content (\%)}

Oil percentage was determined in the fruit flesh on dry weight basis using the Soxhlet oil extraction apparatus with hexane $60-80^{\circ} \mathrm{C}$ boiling point, according to Banat et al. (2013).

\section{Oil acidity (\%)}

It was determined according to the Dieffenbacker and Pocklington (1992), since $5 \mathrm{~g}$ of oil was accurately weighed in $250 \mathrm{ml}$ dry conical flask with about $100 \mathrm{ml}$ of neutralized $50 \%$ ethanol $+50 \%$ petroleum ether to dissolve the oily sample. Acidity of the sample was determined by titration with $0.1 \mathrm{~N}$ of potassium hydroxide solution in the presence of phenolphthalein as an indicator. The acid value was calculated according to the following equation.

$$
\text { Acid percentage }=\frac{V \times N \times 5.61 \times 100}{\text { Weight of sample }}
$$

where

$$
\begin{aligned}
& V=\text { volume of } \mathrm{KOH} \text { solution } \\
& N=\text { normality of potassium hydroxide solution }
\end{aligned}
$$

\section{The peroxide value (meq/ $\mathrm{kg}$ oil)}

The peroxide value was determined according to Jacobs (1959) by dissolving $5 \mathrm{~g}$ of the oil in a mixture consisting of $60 \%$ glacial acetic acid $+40 \%$ chloroform. The solution was treated with approximately $0.5 \mathrm{ml}$ of saturated solution of potassium iodide in glass stoppard flask. The flask was shacked in rotary for exactly 2 min, after which $30 \mathrm{ml}$ of distilled water was added, and the liberated iodine was titrated with $0.01 \mathrm{~N}$ sodium thiosulfate using $1 \%$ of starch solution as external indicator.

The results were calculated in millimoles per kilogram oil according to the following equation. 
Peroxide value $=\frac{0.5 \times \mathrm{N} \times \mathrm{V} \times 100}{\text { Weight of sample }}$

where

$N=$ normality of sodium thiosulfate solution

$V=$ volume in milliliters of sod. thiosulfate needed for titration

\section{lodine value ( $\mathrm{mg} / \mathrm{kg}$ oil)}

The degree of instauration of oil was determined by measuring the amount of halogen absorbed by the oil as stated in Dieffenbacker and Pocklington (1992) since $0.1-0.5 \mathrm{~g}$ of oil was dissolved in $10 \mathrm{ml}$ of chloroform and $25 \mathrm{ml}$ of Hanus iodine solution was added. After $30 \mathrm{~min}$, $10 \mathrm{ml}$ of $15 \%$ potassium iodine solution and $100 \mathrm{ml}$ of freshly boiled cooled distilled water were added. The liberated iodine was titrated with $0.1 \mathrm{~N}$ of sodium thiosulfate using starch indicator.

$$
\text { Iodine value }=\frac{\left(V_{1}-V_{2}\right) \times N \times 12.69}{\text { Weight of sample }}
$$

where

$N=$ normality of sodium thiosulfate solution

$V_{1}=$ volume in milliter of sod. thiosulfate needed for titration blank

$V_{2}=$ volume in milliliter. of sod. thiosulfate needed for titration sample

\section{Experimental design and statistical analysis}

This work was conducted as factorial experiment. Treatments were arranged in a completely randomized block design with three replicates for each treatment. This work was conducted as factorial experiment. Treatments were arranged in a completely randomized block design with three replicates for each treatment. All obtained data during both 2017 and 2018 experimental seasons were subjected to analysis of variances (ANOVA) according to Snedecor and Cochran (1980) using MSTAT program. Least significant ranges (LSR) were used to compare between means of treatments according to Duncan (1955) at probability of 5\%.

\section{Results}

\section{Yield (kg/tree)}

With regard to olive yield per tree, results in the Table 3 cleared that most treatments significantly increased yield than the control in both seasons. In this concern, spraying trees with SAL at $200 \mathrm{ppm}$ (T4) and PUT at $15 \mathrm{ppm}$ + SAL at $200 \mathrm{ppm}+\mathrm{ASC}$ at $2000 \mathrm{ppm}$ (T10) produced the highest yield (33.83 and $33.83 \mathrm{~kg} /$ tree) in the first season. Moreover, foliar spraying with PUT at $15 \mathrm{ppm}+$ SAL at $200 \mathrm{ppm}+\mathrm{ASC}$ at $2000 \mathrm{ppm}$ (T10) recorded the highest value in this respect $(26.31 \mathrm{~kg} /$ tree $)$ in the second season. On the other hand, the control trees exhibited the lowest yield in this regard (25.33 and $17.03 \mathrm{~kg} /$ tree) in both seasons, respectively. On the other side, the other treatments were in between ranges. Concerning spraying dates in the first and second seasons, spraying

Table 3 Influence of foliar applications with putrescine, salicylic, and ascorbic acid on yield and fruit weight of Picual olives in 2017 and 2018 seasons

\begin{tabular}{|c|c|c|c|c|c|c|c|c|c|c|c|c|}
\hline \multirow[t]{4}{*}{ Treat. } & \multicolumn{6}{|c|}{ Yield (kg/tree) } & \multicolumn{6}{|c|}{ Fruit weight (g) } \\
\hline & \multicolumn{3}{|l|}{2017} & \multicolumn{3}{|l|}{2018} & \multicolumn{3}{|l|}{2017} & \multicolumn{3}{|l|}{2018} \\
\hline & \multicolumn{2}{|c|}{ Spraying date } & \multirow[t]{2}{*}{ Mean } & \multicolumn{2}{|c|}{ Spraying date } & \multirow[t]{2}{*}{ Mean } & \multicolumn{2}{|c|}{ Spraying date } & \multirow[t]{2}{*}{ Mean } & \multicolumn{2}{|c|}{ Spraying date } & \multirow[t]{2}{*}{ Mean } \\
\hline & Nov. & Dec. & & Nov. & Dec. & & Nov. & Dec. & & Nov. & Dec. & \\
\hline Cont. & $25.00 \mathrm{e}$ & 25.67 de & $25.33 \mathrm{C}$ & $16.96 \mathrm{i}$ & $17.10 i$ & $17.03 \mathrm{G}$ & $5.10 \mathrm{fg}$ & $4.93 \mathrm{~g}$ & $5.02 \mathrm{C}$ & $5.60 \mathrm{k}$ & $5.64 \mathrm{jk}$ & $5.62 \mathrm{~K}$ \\
\hline T1 & 30.00 a-e & 28.00 cde & $29.00 \mathrm{~B}$ & $19.56 \mathrm{~h}$ & $19.47 \mathrm{~h}$ & $19.51 \mathrm{~F}$ & $5.93 \mathrm{a}-\mathrm{e}$ & $5.81 \mathrm{~b}-\mathrm{e}$ & $5.87 A B$ & $5.60 \mathrm{k}$ & $5.80 \mathrm{ijk}$ & $5.70 \mathrm{~J}$ \\
\hline $\mathrm{T} 2$ & $29.00 \mathrm{~b}-\mathrm{e}$ & $30.66 a-d$ & 29.83 B & $19.93 \mathrm{gh}$ & $20.90 \mathrm{~g}$ & $20.41 \mathrm{E}$ & 5.60 def & $5.70 c-f$ & $5.65 \mathrm{~B}$ & $5.63 \mathrm{jk}$ & $6.00 \mathrm{hi}$ & 5.811 \\
\hline T3 & $32.00 \mathrm{abc}$ & $26.00 \mathrm{de}$ & $29.00 \mathrm{~B}$ & 23.06 ef & $20.59 \mathrm{gh}$ & $21.83 \mathrm{D}$ & $6.22 \mathrm{abc}$ & $5.63 c-f$ & $5.93 \mathrm{AB}$ & $6.00 \mathrm{hi}$ & $6.16 \mathrm{gh}$ & $6.08 \mathrm{H}$ \\
\hline T4 & 34.67 a & $33.00 \mathrm{abc}$ & $33.83 \mathrm{~A}$ & 23.96 de & 23.17 ef & $23.56 \mathrm{C}$ & $5.97 \mathrm{a}-\mathrm{e}$ & $6.41 \mathrm{ab}$ & $6.19 \mathrm{~A}$ & $6.20 \mathrm{fgh}$ & 6.40 efg & $6.30 \mathrm{~F}$ \\
\hline T5 & $32.33 \mathrm{abc}$ & 28.00 cde & 30.17 B & 24.23 cde & $22.30 \mathrm{f}$ & $23.26 \mathrm{C}$ & $5.91 \mathrm{a}-\mathrm{e}$ & $5.86 \mathrm{a}-\mathrm{e}$ & $5.89 A B$ & 5.97 hij & 6.44 efg & $6.20 \mathrm{G}$ \\
\hline T6 & $33.66 \mathrm{ab}$ & $29.33 \mathrm{~b}-\mathrm{e}$ & $31.50 \mathrm{AB}$ & $23.26 \mathrm{ef}$ & 24.13 cde & $23.70 \mathrm{C}$ & $6.39 \mathrm{ab}$ & $6.16 a-d$ & $6.28 \mathrm{~A}$ & $6.85 \mathrm{bcd}$ & $7.17 \mathrm{~b}$ & $7.01 \mathrm{~B}$ \\
\hline T7 & $30.33 \mathrm{a}-\mathrm{d}$ & 26.00 de & 28.17 BC & 23.93 de & $20.16 \mathrm{gh}$ & $22.05 \mathrm{D}$ & $6.17 a-d$ & $5.85 \mathrm{a}-\mathrm{e}$ & $6.01 A B$ & $6.30 \mathrm{fgh}$ & 6.70 cde & $6.50 \mathrm{E}$ \\
\hline T8 & 28.33 cde & 30.00 a-e & 29.17 B & $24.66 \mathrm{bcd}$ & $23.10 \mathrm{ef}$ & $23.88 \mathrm{C}$ & 5.50 efg & $6.39 \mathrm{ab}$ & $5.95 \mathrm{AB}$ & 6.55 def & $7.00 \mathrm{bc}$ & $6.77 \mathrm{D}$ \\
\hline T9 & $32.33 \mathrm{abc}$ & 28.00 cde & 30.17 B & $25.26 \mathrm{bc}$ & $24.63 \mathrm{bcd}$ & 24.95 B & 5.54 efg & $4.94 \mathrm{~g}$ & $5.24 \mathrm{C}$ & 6.66 cde & $7.13 b$ & $6.89 \mathrm{C}$ \\
\hline T10 & $33.00 \mathrm{abc}$ & $34.67 \mathrm{a}$ & $33.83 \mathrm{~A}$ & $25.73 b$ & $26.90 \mathrm{a}$ & $26.31 \mathrm{~A}$ & $6.12 \mathrm{a}-\mathrm{e}$ & $6.45 \mathrm{a}$ & $6.28 \mathrm{~A}$ & $7.06 \mathrm{~b}$ & $7.63 \mathrm{a}$ & $7.34 \mathrm{~A}$ \\
\hline Mean & $30.97 A^{*}$ & $29.03 B^{*}$ & & $22.78 A^{*}$ & $22.04 B^{*}$ & & $5.86 A^{*}$ & $5.83 A^{*}$ & & $6.22 B^{*}$ & $6.55 A^{*}$ & \\
\hline
\end{tabular}

*Mean in each column, row, or interaction with similar letter(s) are not significantly different at $5 \%$ level

T1 PUT at 15 ppm, T2 PUT at 30 ppm, T3 SAL at 200 ppm, T4 SAL at 300 ppm, T5 ASC at 2000 ppm, T6 ASC at 3000 ppm, T7 PUT at 15 ppm + SAL at 200 ppm, T8 PUT at 15 ppm + ASC at 2000 ppm, T9 SAL at 200 ppm + ASC at 2000 ppm, T10 PUT at 15 ppm + SAL at 200 ppm + ASC at 2000 ppm 
in November gave higher yield (30.97 and $22.78 \mathrm{~kg} /$ tree) as compared with spraying in December (29.03 and $22.04 \mathrm{~kg} /$ tree), respectively. Concerning interaction effect, spraying trees in December with PUT at $15 \mathrm{ppm}+$ SAL at $200 \mathrm{ppm}+\mathrm{ASC}$ at $2000 \mathrm{ppm}$ (T10) gave the highest value (34.67 and $26.90 \mathrm{~kg} / \mathrm{tree})$ in both studied seasons, respectively.

\section{Physical properties of olive fruit Fruit weight}

Regarding fruit weight, results in Table 3 cleared that all treatments except T9 in the first season significantly enhanced fruit weight than the control in both studied seasons. In this manner, spraying trees with ASC at $3000 \mathrm{ppm}$ (T6) and PUT at $15 \mathrm{ppm}+\mathrm{SAL}$ at $200 \mathrm{ppm}+\mathrm{ASC}$ at $2000 \mathrm{ppm}$ (T10) exhibited the highest fruit weight (6.28 and $6.28 \mathrm{~g})$ in the first season. Meanwhile, trees sprayed with PUT at 15 ppm + SAL at $200 \mathrm{ppm}+\mathrm{ASC}$ at $2000 \mathrm{ppm}$ (T10) recorded the highest value in this respect $(7.34 \mathrm{~g})$ in the second one. On the other hand, control treatment recorded the least values (5.02 and $5.62 \mathrm{~g}$ ) in both studied seasons, respectively. With regard to spraying dates, results showed no significant differences between spraying dates in the first season, while in the second one, spraying date of December recorded significantly higher value $(6.55 \mathrm{~g})$ than the November one $(6.22$ g) in this respect. Concerning the interaction effect, results showed that spraying with PUT at $15 \mathrm{ppm}+\mathrm{SAL}$ at 200 $\mathrm{ppm}+\mathrm{ASC}$ at $2000 \mathrm{ppm}$ (T10) at December gave the highest values of fruit weight (6.45 and $7.63 \mathrm{~g}$ ) in the both seasons of this study, respectively.

\section{Pulp weight}

Data in Table 4 indicated that pulp weight was significantly affected by different spraying treatments as compared with control in both studied seasons except T9 in the first season. Application of PUT at $15 \mathrm{ppm}+\mathrm{SAL}$ at $200 \mathrm{ppm}+\mathrm{ASC}$ at $2000 \mathrm{ppm}$ (T10) recorded the maximum values in this respect since there were (5.51 and $6.40 \mathrm{~g}$ ) in both studied seasons, respectively. However, the minimum values were shown with the control (4.14 and $4.77 \mathrm{~g}$ ) in the first and second seasons, respectively. Moreover, the time of foliar spraying shows that no significant differences between spraying dates in the first season, but December application date was significantly higher $(5.67 \mathrm{~g})$ than November $(5.27 \mathrm{~g})$ in the second season. Concerning the interaction effect, trees sprayed with PUT at 15 ppm + ASC at 2000 ppm (T8) at December recorded the highest significant value $(5.71 \mathrm{~g})$ in the first season. However, trees sprayed with PUT at $15 \mathrm{ppm}$ + SAL at $200 \mathrm{ppm}+\mathrm{ASC}$ at $2000 \mathrm{ppm}$ (T10) in December presented the highest value in this respect $(6.67 \mathrm{~g})$ in the second season.

\section{Pulp to seed ratio}

Regard to pulp to seed ratio, results in the Table 4 illustrated that all spraying treatments except $\mathrm{T} 1$ in the second season significantly increased pulp to seed ratio than the control in the first and second seasons, respectively. In this concern, spraying trees with PUT at 15 $\mathrm{ppm}+\mathrm{SAL}$ at $200 \mathrm{ppm}+\mathrm{ASC}$ at $2000 \mathrm{ppm}$ (T10) produced the largest values (7.11) in this regard during the

Table 4 Influence of foliar applications with putrescine, salicylic, and ascorbic acid on fruit weight, pulp weight, and pulp/seed ratio of Picual olives in 2017 and 2018 seasons

\begin{tabular}{|c|c|c|c|c|c|c|c|c|c|c|c|c|}
\hline \multirow[t]{4}{*}{ Treat. } & \multicolumn{6}{|c|}{ Pulp weight (g) } & \multicolumn{6}{|c|}{ Pulp/seed ratio } \\
\hline & \multicolumn{3}{|l|}{2017} & \multicolumn{3}{|l|}{2018} & \multicolumn{3}{|l|}{2017} & \multicolumn{3}{|l|}{2018} \\
\hline & \multicolumn{2}{|c|}{ Spraying date } & \multirow[t]{2}{*}{ Mean } & \multicolumn{2}{|c|}{ Spraying date } & \multirow[t]{2}{*}{ Mean } & \multicolumn{2}{|c|}{ Spraying date } & \multirow[t]{2}{*}{ Mean } & \multicolumn{2}{|c|}{ Spraying date } & \multirow[t]{2}{*}{ Mean } \\
\hline & $\overline{\text { Nov. }}$ & Dec. & & $\overline{\text { Nov. }}$ & Dec. & & $\overline{N o v}$. & Dec. & & Nov. & Dec. & \\
\hline Cont. & $4.22 \mathrm{gh}$ & $4.07 \mathrm{~h}$ & $4.14 \mathrm{E}$ & $4.74 \mathrm{fg}$ & 4.80 efg & $4.77 \mathrm{~K}$ & $4.79 \mathrm{gh}$ & $4.72 \mathrm{~h}$ & $4.76 \mathrm{~F}$ & $5.56 \mathrm{gh}$ & $5.71 \mathrm{fg}$ & $5.64 \mathrm{~F}$ \\
\hline T1 & $5.07 c-f$ & 4.93 def & $5.00 \mathrm{CD}$ & $4.71 \mathrm{~g}$ & 4.94 efg & $4.82 \mathrm{~J}$ & $5.86 \mathrm{~d}-\mathrm{h}$ & $5.64 \mathrm{e}-\mathrm{h}$ & $5.75 \mathrm{DE}$ & $5.29 \mathrm{~h}$ & $5.77 \mathrm{fg}$ & $5.52 \mathrm{~F}$ \\
\hline $\mathrm{T} 2$ & 4.82 ef & 4.93 def & $4.87 \mathrm{D}$ & $4.80 \mathrm{fg}$ & $5.18 \mathrm{~d}-\mathrm{g}$ & 4.991 & 6.18 def & $6.37 b-f$ & 6.27 BCD & $5.85 \mathrm{fg}$ & 6.35 cde & $6.10 \mathrm{E}$ \\
\hline T3 & $5.49 \mathrm{a}-\mathrm{d}$ & $4.84 \mathrm{ef}$ & $5.16 \mathrm{AD}$ & $5.19 c-g$ & $5.34 c-g$ & $5.27 \mathrm{G}$ & $7.50 \mathrm{ab}$ & 6.09 def & $6.79 \mathrm{ABC}$ & 6.46 cde & $6.54 \mathrm{~cd}$ & $6.51 \mathrm{CD}$ \\
\hline T4 & $5.18 \mathrm{a}-\mathrm{f}$ & $5.61 \mathrm{abc}$ & 5.39ABC & $5.39 b-f$ & $5.56 b-f$ & $5.47 \mathrm{E}$ & $6.53 \mathrm{~b}-f$ & $7.01 \mathrm{bcd}$ & $6.77 \mathrm{ABC}$ & $6.71 \mathrm{bc}$ & $6.65 \mathrm{bcd}$ & $6.68 \mathrm{BC}$ \\
\hline T5 & 5.09 b-f & 4.97 def & $5.03 \mathrm{BCD}$ & $5.19 c-g$ & $5.53 b-f$ & $5.36 \mathrm{~F}$ & $6.22 c-f$ & $5.61 \mathrm{e}-\mathrm{h}$ & 5.91 DE & $6.65 \mathrm{bcd}$ & 6.09 ef & $6.37 \mathrm{D}$ \\
\hline T6 & $5.45 \mathrm{a}-\mathrm{d}$ & 5.37 a-e & $5.41 \mathrm{AB}$ & $6.03 a b c$ & $6.23 \mathrm{ab}$ & $6.13 \mathrm{~B}$ & $5.90 \mathrm{~d}-\mathrm{h}$ & $6.74 \mathrm{~b}-\mathrm{e}$ & $6.32 \mathrm{BCD}$ & $7.42 \mathrm{a}$ & $6.62 \mathrm{bcd}$ & $7.02 \mathrm{~A}$ \\
\hline T7 & $5.33 \mathrm{a}-\mathrm{e}$ & 5.00 def & $5.16 \mathrm{~A}-\mathrm{D}$ & $5.43 b-f$ & $5.82 \mathrm{a}-\mathrm{d}$ & $5.12 \mathrm{H}$ & $6.30 c-f$ & $5.93 \mathrm{~d}-\mathrm{g}$ & $6.11 \mathrm{CDE}$ & 6.27 de & $6.67 \mathrm{bcd}$ & $6.47 \mathrm{CD}$ \\
\hline T8 & $4.65 \mathrm{fg}$ & $5.71 \mathrm{a}$ & 5.18 A-D & 5.67 b-e & $6.09 a b$ & $5.88 \mathrm{D}$ & $5.52 \mathrm{fgh}$ & $8.41 \mathrm{a}$ & $6.96 \mathrm{AB}$ & 6.44 cde & $6.74 b c$ & 6.59BCD \\
\hline T9 & $4.67 \mathrm{fg}$ & $4.18 \mathrm{gh}$ & $4.42 \mathrm{E}$ & $5.78 \mathrm{a}-\mathrm{d}$ & $6.20 \mathrm{ab}$ & $5.99 \mathrm{C}$ & $5.48 \mathrm{fgh}$ & $5.48 \mathrm{fgh}$ & $5.48 \mathrm{E}$ & $6.60 \mathrm{bcd}$ & $6.66 \mathrm{bcd}$ & $6.63 \mathrm{BCD}$ \\
\hline T10 & $5.34 \mathrm{a}-\mathrm{e}$ & $5.68 a b$ & $5.51 \mathrm{~A}$ & $6.13 a b$ & $6.67 \mathrm{a}$ & $6.40 \mathrm{~A}$ & $6.84 \mathrm{bcd}$ & $7.37 \mathrm{abc}$ & $7.11 \mathrm{~A}$ & $6.64 \mathrm{bcd}$ & $6.97 b$ & $6.81 \mathrm{AB}$ \\
\hline Mean & $5.03 \mathrm{~A}^{*}$ & $5.02 A^{*}$ & & $5.27 \mathrm{~B}^{*}$ & $5.67 A^{*}$ & & $6.10 A^{*}$ & $6.31 A^{*}$ & & $6.35 A^{*}$ & $6.44 A^{*}$ & \\
\hline
\end{tabular}

*Mean in each column, row, or interaction with similar letter(s) are not significantly different at $5 \%$ level

T1 PUT at 15 ppm, T2 PUT at 30 ppm, T3 SAL at 200 ppm, T4 SAL at 300 ppm, T5 ASC at 2000 ppm, T6 ASC at 3000 ppm, T7 PUT at 15 ppm + SAL at 200 ppm, T8 PUT at 15 ppm + ASC at 2000 ppm, T9 SAL at 200 ppm + ASC at 2000 ppm, T10 PUT at 15 ppm + SAL at 200 ppm + ASC at 2000 ppm 
first season; moreover, spraying trees with ASC at 3000 ppm (T6) showed the highest value (7.02) in the second season, respectively. Concerning spraying dates, no significant differences between spraying dates were found in the first and second seasons, respectively. Concerning interaction influence, spraying trees in December with PUT at $15 \mathrm{ppm}+\mathrm{ASC}$ at $2000 \mathrm{ppm}$ (T8) gave the highest value (8.41) in the first season. On the other hand, spraying trees with ASC at $3000 \mathrm{ppm}$ (T6) at November gave the largest value (7.42) in this regard in the second season compared with other treatments.

\section{Fruit length}

Data in Table 5 indicated that fruit length was significantly affected by different treatments compared with control in both studied seasons. In the first season, application of ASC at $2000 \mathrm{ppm}$ (T5) gave the highest values in this respect since $(2.69 \mathrm{~cm})$. But in the second season, application of PUT at $15 \mathrm{ppm}+\mathrm{SAL}$ at $200 \mathrm{ppm}+\mathrm{ASC}$ at $2000 \mathrm{ppm}$ (T10) recorded the highest value of fruit length $(2.86 \mathrm{~cm})$ in this respect, while the least significant values were shown with untreated trees (control) $(2.44$ and $2.42 \mathrm{~cm})$ in both studied seasons, respectively. Moreover, the time of foliar spraying showed that November application date had more significant higher value $(2.62 \mathrm{~cm})$ than December $(2.60 \mathrm{~cm})$ in the first season, but in the second season, results showed that December application date recoded more significant higher $(2.70 \mathrm{~cm})$ than November $(2.60 \mathrm{~cm})$ in this regard. Concerning interaction effect, trees sprayed with PUT at $15 \mathrm{ppm}$ $+\mathrm{SAL}$ at $200 \mathrm{ppm}+\mathrm{ASC}$ at $2000 \mathrm{ppm}$ (T10) and ASC at $2000 \mathrm{ppm}$ (T5) in December recorded the largest significant values $(2.70$ and $2.70 \mathrm{~cm})$ in the first season. But trees sprayed with PUT at $15 \mathrm{ppm}+\mathrm{SAL}$ at $200 \mathrm{ppm}+\mathrm{ASC}$ at $2000 \mathrm{ppm}$ (T10) in December presented the highest fruit length $(2.90 \mathrm{~cm})$ in the second season.

\section{Fruit diameter}

Data in Table 5 indicated that fruit diameter was significantly affected by different treatments compared with control in both studied seasons. In the first season, application of SAL at $300 \mathrm{ppm}$ (T4) gave the maximum fruit diameter $(2.13 \mathrm{~cm})$. Moreover, in the second one, spraying with PUT at $15 \mathrm{ppm}+\mathrm{SAL}$ at $200 \mathrm{ppm}+\mathrm{ASC}$ at $2000 \mathrm{ppm}$ (T10) recorded the maximum value $(2.17$ $\mathrm{cm}$ ) in this respect, while the significant lowest values were shown with control treatment $(1.95$ and $1.93 \mathrm{~cm})$ in the first and second seasons, respectively. Moreover, the time of spraying shows that there was no significant difference found between the two spraying dates in the first season, while in the second one, December spraying date had significant higher value $(2.07 \mathrm{~cm})$ than the November one $(2.03 \mathrm{~cm})$ in this respect. Regarding interaction effect, trees sprayed with SAL at $300 \mathrm{ppm}$ (T4) at December and PUT at $15 \mathrm{ppm}+\mathrm{SAL}$ at $200 \mathrm{ppm}+\mathrm{ASC}$ at $2000 \mathrm{ppm}$ (T10) at December recorded the largest significant fruit diameter $(2.19$ and $2.20 \mathrm{~cm})$ in the first and second seasons, sequently.

Table 5 Influence of foliar applications with putrescine, salicylic, and ascorbic acid on fruit length and diameter of Picual olives in 2017 and 2018 seasons

\begin{tabular}{|c|c|c|c|c|c|c|c|c|c|c|c|c|}
\hline \multirow[t]{4}{*}{ Treat. } & \multicolumn{6}{|c|}{ Fruit length $(\mathrm{cm})$} & \multicolumn{6}{|c|}{ Fruit diameter $(\mathrm{cm})$} \\
\hline & \multicolumn{3}{|l|}{2017} & \multicolumn{3}{|l|}{2018} & \multicolumn{3}{|l|}{2017} & \multicolumn{3}{|l|}{2018} \\
\hline & \multicolumn{2}{|c|}{ Spraying date } & \multirow[t]{2}{*}{ Mean } & \multicolumn{2}{|c|}{ Spraying date } & \multirow[t]{2}{*}{ Mean } & \multicolumn{2}{|c|}{ Spraying date } & \multirow[t]{2}{*}{ Mean } & \multicolumn{2}{|c|}{ Spraying date } & \multirow[t]{2}{*}{ Mean } \\
\hline & Nov. & Dec. & & Nov. & Dec. & & Nov. & Dec. & & Nov. & Dec. & \\
\hline Cont. & $2.42 \mathrm{~g}$ & $2.46 \mathrm{fg}$ & $2.44 \mathrm{C}$ & $2.40 \mathrm{c}$ & $2.44 b c$ & $2.42 I$ & $1.93 \mathrm{j}$ & 1.98 hij & $1.95 \mathrm{~F}$ & $1.88 \mathrm{~d}$ & $1.98 \mathrm{bcd}$ & $1.93 \mathrm{~J}$ \\
\hline $\mathrm{T} 1$ & $2.69 \mathrm{a}$ & $2.46 \mathrm{fg}$ & $2.57 \mathrm{~B}$ & $2.42 \mathrm{C}$ & $2.54 \mathrm{abc}$ & $2.48 \mathrm{H}$ & $2.05 \mathrm{~d}-\mathrm{g}$ & $2.11 \mathrm{bcd}$ & $2.08 \mathrm{BC}$ & $1.92 \mathrm{~cd}$ & $1.96 \mathrm{bcd}$ & $1.94 I$ \\
\hline $\mathrm{T} 2$ & $2.60 \mathrm{a}-\mathrm{e}$ & $2.66 a b c$ & $2.63 A B$ & $2.48 \mathrm{abc}$ & $2.60 \mathrm{abc}$ & $2.54 \mathrm{G}$ & $2.02 \mathrm{e}-\mathrm{h}$ & 2.00 ghi & 2.01 DE & $2.00 a-d$ & $2.02 \mathrm{a}-\mathrm{d}$ & $2.01 \mathrm{H}$ \\
\hline T3 & $2.64 a-d$ & $2.56 \mathrm{c}-\mathrm{f}$ & $2.61 \mathrm{~B}$ & $2.54 a b c$ & $2.62 a b c$ & $2.58 \mathrm{~F}$ & $2.12 b c$ & $2.07 c-f$ & $2.09 A B C$ & $2.04 a-d$ & $2.06 \mathrm{a}-\mathrm{d}$ & $2.05 \mathrm{G}$ \\
\hline T4 & $2.64 a-d$ & $2.51 \mathrm{efg}$ & $2.58 \mathrm{~B}$ & $2.70 a b c$ & $2.66 \mathrm{abc}$ & $2.68 \mathrm{D}$ & 2.08 cde & $2.19 a$ & $2.13 \mathrm{~A}$ & $2.06 a-d$ & $2.08 \mathrm{a}-\mathrm{d}$ & $2.07 \mathrm{E}$ \\
\hline T5 & $2.68 \mathrm{ab}$ & $2.70 \mathrm{a}$ & $2.69 \mathrm{~A}$ & $2.62 a b c$ & $2.68 \mathrm{abc}$ & $2.65 \mathrm{E}$ & 2.08 cde & $2.01 \mathrm{f}-\mathrm{i}$ & $2.04 C D$ & $2.02 a-d$ & $2.14 a b$ & $2.08 \mathrm{D}$ \\
\hline T6 & $2.66 \mathrm{abc}$ & $2.69 a$ & $2.68 \mathrm{~A}$ & $2.72 a b c$ & $2.84 \mathrm{abc}$ & $2.78 \mathrm{~B}$ & $2.12 b c$ & $2.06 \mathrm{~d}-\mathrm{g}$ & $2.09 \mathrm{ABC}$ & $2.12 a b c$ & $2.14 a b$ & $2.13 \mathrm{~B}$ \\
\hline T7 & $2.67 \mathrm{abc}$ & 2.59 a-e & $2.63 \mathrm{AB}$ & $2.62 a b c$ & $2.74 a b c$ & $2.68 \mathrm{D}$ & $2.11 \mathrm{bcd}$ & 2.08 cde & $2.10 A B$ & $2.02 a-d$ & $2.10 a b c$ & $2.06 \mathrm{~F}$ \\
\hline T8 & $2.57 \mathrm{~b}-\mathrm{e}$ & $2.62 a-d$ & $2.60 \mathrm{~B}$ & $2.66 \mathrm{abc}$ & $2.80 \mathrm{abc}$ & $2.73 \mathrm{C}$ & $2.03 \mathrm{e}-\mathrm{h}$ & $2.17 \mathrm{ab}$ & $2.10 A B$ & $2.10 a b c$ & $2.02 \mathrm{a}-\mathrm{d}$ & $2.06 \mathrm{~F}$ \\
\hline T9 & $2.63 a-d$ & 2.54 def & $2.58 \mathrm{~B}$ & $2.67 \mathrm{abc}$ & $2.88 \mathrm{ab}$ & $2.77 \mathrm{~B}$ & $2.01 \mathrm{f}-\mathrm{i}$ & $1.95 \mathrm{ij}$ & $1.98 \mathrm{EF}$ & $2.10 a b c$ & $2.12 \mathrm{abc}$ & $2.11 \mathrm{C}$ \\
\hline T10 & $2.66 \mathrm{abc}$ & $2.70 \mathrm{a}$ & $2.68 \mathrm{~A}$ & $2.82 \mathrm{abc}$ & $2.90 \mathrm{a}$ & $2.86 \mathrm{~A}$ & $2.06 \mathrm{~d}-\mathrm{g}$ & 2.08 cde & $2.07 \mathrm{BC}$ & $2.14 a b$ & $2.20 \mathrm{a}$ & $2.17 \mathrm{~A}$ \\
\hline Mean & $2.62 A^{*}$ & $2.59 B^{*}$ & & $2.60 B^{*}$ & $2.70 A^{*}$ & & $2.05 A^{*}$ & $2.06 A^{*}$ & & $2.03 B^{*}$ & $2.07 A^{*}$ & \\
\hline
\end{tabular}

*Mean in each column, row, or interaction with similar letter(s) are not significantly different at $5 \%$ level

T1 PUT at 15 ppm, T2 PUT at 30 ppm, T3 SAL at 200 ppm, T4 SAL at 300 ppm, T5 ASC at 2000 ppm, T6 ASC at 3000 ppm, T7 PUT at 15 ppm + SAL at 200 ppm, T8 PUT at $15 \mathrm{ppm}+\mathrm{ASC}$ at $2000 \mathrm{ppm}$, T9 SAL at $200 \mathrm{ppm}+\mathrm{ASC}$ at $2000 \mathrm{ppm}$, T10 PUT at $15 \mathrm{ppm}+\mathrm{SAL}$ at $200 \mathrm{ppm}+\mathrm{ASC}$ at $2000 \mathrm{ppm}$ 


\section{Fruit oil content}

Results presented in Table 6 revealed that the most different spraying treatments in the first season and all treatments in the second one significantly increased fruit oil percentage on dry weight basis than the control during both seasons. Trees sprayed with PUT at $15 \mathrm{ppm}+$ SAL at $200 \mathrm{ppm}+\mathrm{ASC}$ at $2000 \mathrm{ppm}$ (T10) gave the maximum fruit oil percentages (39.92 and $40.49 \%$ ) in the first and second seasons, respectively. On the other side, the control trees recorded the lowest oil percentage (33.25 and 35.45\%) in both studied seasons, respectively. Meanwhile, the other treatments were in between ranges. Concerning spraying dates, there were no significant differences in fruit oil percentage between the two spraying dates in the first season, but in the second season, December spray recorded the higher value (38.47\%) as compared with November spraying date $(37.62 \%)$ in this respect. As for interaction effect between different foliar application treatments and spraying dates, it could be concluded that there were no significant differences in fruit oil content between different treatments and spraying dates in the first season; however, trees sprayed with PUT at $15 \mathrm{ppm}+\mathrm{SAL}$ at $200 \mathrm{ppm}+\mathrm{ASC}$ at 2000 ppm (T10) in December recorded the highest oil content $(40.73 \%)$ in the second season.

\section{Chemical properties of fruit oil Oil acidity}

Data in Table 6 indicated that oil acidity was significantly affected by different treatments and spraying dates and it range from 0.16 to $0.51 \%$ in the first season, while in the second one, it ranged between 0.20 and $0.49 \%$. However, the lowest oil acidity was found with trees sprayed by ASC at $2000 \mathrm{ppm}$ (T5) (0.21 and 0.24\%) in both studied seasons, respectively. Meanwhile, the highest oil acidity was recorded with PUT at $15 \mathrm{ppm}$ (T1) $(0.39$ and $0.42 \%)$ in the first and second seasons, respectively. As for spraying dates, results clear that spraying dates in December (0.26 and $0.26 \%)$ significantly decreased oil acidity compared with November (0.39 and $0.39 \%$ ) in both studied seasons, respectively. Regarding interaction effect in between the different concentrations treatments and spraying dates, spraying by ASC at 2000 ppm (T5) in December presented the lowest oil acidity percentages $(0.16$ and $0.20 \%)$ in the first and second seasons, respectively. On the other side, trees sprayed with SAL at $300 \mathrm{ppm}$ (T4) in November and PUT at $15 \mathrm{ppm}$ (T1) in November recorded the highest values $(0.51$ and $0.49 \%$ in this respect in both seasons of the study, respectively.

\section{Peroxide value}

Results in Table 7 reported that peroxide value was significantly affected with different foliar application treatments and spraying dates in both seasons. However, peroxide values ranged from 3.36 to $5.05 \mathrm{meq} / \mathrm{kg}$ and 3.48 to $5.11 \mathrm{meq} / \mathrm{kg}$ in the first and second seasons, respectively. On the other hand, the lowest peroxide values (3.61 and $3.66 \mathrm{meq} / \mathrm{kg}$ ) were obtained with trees sprayed with PUT at $15 \mathrm{ppm}+\mathrm{ASC}$ at $2000 \mathrm{ppm}$ (T8) in the first

Table 6 Influence of foliar applications with putrescine, salicylic, and ascorbic acid on flesh oil content and oil acidity of Picual olives in 2017 and 2018 seasons

\begin{tabular}{|c|c|c|c|c|c|c|c|c|c|c|c|c|}
\hline \multirow[t]{4}{*}{ Treat. } & \multicolumn{6}{|c|}{ Flesh oil content (\%) } & \multicolumn{6}{|c|}{ Oil acidity (\%) } \\
\hline & \multicolumn{3}{|l|}{2017} & \multicolumn{3}{|l|}{2018} & \multicolumn{3}{|l|}{2017} & \multicolumn{3}{|l|}{2018} \\
\hline & \multicolumn{2}{|c|}{ Spraying date } & \multirow[t]{2}{*}{ Mean } & \multicolumn{2}{|c|}{ Spraying date } & \multirow[t]{2}{*}{ Mean } & \multicolumn{2}{|c|}{ Spraying date } & \multirow[t]{2}{*}{ Mean } & \multicolumn{2}{|c|}{ Spraying date } & \multirow[t]{2}{*}{ Mean } \\
\hline & Nov. & Dec. & & Nov. & Dec. & & Nov. & Dec. & & Nov. & Dec. & \\
\hline Cont. & $33.18 \mathrm{ab}$ & $33.32 \mathrm{ab}$ & $33.25 \mathrm{~B}$ & $35.60 \mathrm{~lm}$ & $35.30 \mathrm{~m}$ & $35.45 \mathrm{H}$ & $0.38 a-f$ & $0.37 a-f$ & $0.37 \mathrm{~B}$ & $0.39 a-d$ & $0.38 \mathrm{a}-\mathrm{d}$ & $0.38 \mathrm{~B}$ \\
\hline $\mathrm{T} 1$ & $33.63 a b$ & $37.87 \mathrm{a}$ & $35.75 \mathrm{AB}$ & $36.03 \mathrm{kl}$ & $38.34 \mathrm{~h}$ & $37.18 \mathrm{~F}$ & $0.47 \mathrm{a}-\mathrm{d}$ & $0.32 \mathrm{~b}-\mathrm{g}$ & $0.39 \mathrm{~A}$ & $0.49 \mathrm{a}$ & $0.36 \mathrm{a}-\mathrm{e}$ & $0.42 \mathrm{~A}$ \\
\hline T2 & $33.73 a b$ & 39.39 a & $36.56 \mathrm{AB}$ & $36.56 j$ & 39.83 cde & $38.20 \mathrm{C}$ & $0.49 a b$ & $0.23 \mathrm{efg}$ & $0.36 \mathrm{C}$ & $0.48 \mathrm{a}$ & $0.31 \mathrm{~b}-\mathrm{f}$ & $0.39 \mathrm{~B}$ \\
\hline T3 & $35.62 \mathrm{ab}$ & $37.87 \mathrm{a}$ & $36.74 \mathrm{AB}$ & 35.781 & 39.39 ef & $37.58 \mathrm{E}$ & $0.48 a b c$ & $0.29 \mathrm{~d}-\mathrm{g}$ & $0.38 \mathrm{AB}$ & $0.47 a$ & 0.25 def & $0.36 \mathrm{C}$ \\
\hline T4 & 38.98 a & $38.93 \mathrm{a}$ & $38.95 \mathrm{AB}$ & $40.10 \mathrm{~cd}$ & $40.63 a b$ & $40.37 \mathrm{~A}$ & $0.51 \mathrm{a}$ & $0.27 \mathrm{efg}$ & $0.39 \mathrm{~A}$ & $0.46 a b$ & 0.24 def & $0.35 \mathrm{D}$ \\
\hline T5 & 39.13 a & 38.35 a & 38.74 AB & $38.99 \mathrm{fg}$ & $38.50 \mathrm{~h}$ & 38.75 B & $0.27 \mathrm{efg}$ & $0.16 \mathrm{~g}$ & $0.21 \mathrm{G}$ & $0.29 c-f$ & $0.20 \mathrm{f}$ & $0.24 \mathrm{H}$ \\
\hline T6 & $40.00 \mathrm{a}$ & $28.98 \mathrm{~b}$ & $34.49 \mathrm{AB}$ & 39.69 de & $41.01 \mathrm{a}$ & $40.35 \mathrm{~A}$ & 0.41 a-e & $0.22 \mathrm{fg}$ & $0.31 \mathrm{D}$ & $0.42 a b c$ & 0.22 ef & $0.32 \mathrm{E}$ \\
\hline T7 & $35.50 \mathrm{ab}$ & $35.61 \mathrm{ab}$ & $35.55 \mathrm{AB}$ & $36.34 \mathrm{jk}$ & $36.06 \mathrm{kl}$ & $36.20 \mathrm{G}$ & $0.32 \mathrm{a}-\mathrm{g}$ & $0.25 \mathrm{efg}$ & $0.28 \mathrm{E}$ & $0.35 a-f$ & $0.27 c-f$ & $0.31 \mathrm{~F}$ \\
\hline T8 & $34.84 a b$ & $35.80 \mathrm{ab}$ & $35.32 \mathrm{AB}$ & 35.801 & $36.28 \mathrm{jk}$ & $36.20 \mathrm{G}$ & $0.31 \mathrm{~b}-\mathrm{g}$ & $0.25 \mathrm{efg}$ & $0.28 \mathrm{E}$ & 0.36 a-e & 0.21 ef & $0.28 \mathrm{G}$ \\
\hline T9 & $37.80 \mathrm{ab}$ & $36.28 a b$ & $37.04 \mathrm{AB}$ & $38.72 \mathrm{gh}$ & $37.12 \mathrm{i}$ & $37.92 \mathrm{D}$ & $0.35 \mathrm{a}-\mathrm{g}$ & $0.26 \mathrm{efg}$ & $0.30 \mathrm{D}$ & $0.35 a-f$ & 0.24 def & $0.29 \mathrm{G}$ \\
\hline T10 & $40.60 \mathrm{a}$ & $39.24 \mathrm{a}$ & $39.92 \mathrm{~A}$ & 40.24 bc & $40.73 \mathrm{a}$ & $40.49 \mathrm{~A}$ & $0.29 c-g$ & $0.21 \mathrm{fg}$ & $0.25 \mathrm{~F}$ & $0.30 c-f$ & 0.21 ef & $0.25 \mathrm{H}$ \\
\hline Mean & $36.63 A^{*}$ & $36.51 A^{*}$ & & $37.62 \mathrm{~B}^{*}$ & $38.47 \mathrm{~A}^{*}$ & & $0.39 A^{*}$ & $0.26 B^{*}$ & & $0.39 A^{*}$ & $0.26 B^{*}$ & \\
\hline
\end{tabular}

*Mean in each column, row, or interaction with similar letter(s) are not significantly different at $5 \%$ level

T1 PUT at 15 ppm, T2 PUT at 30 ppm, T3 SAL at 200 ppm, T4 SAL at 300 ppm, T5 ASC at 2000 ppm, T6 ASC at 3000 ppm, T7 PUT at 15 ppm + SAL at 200 ppm, T8 PUT at 15 ppm + ASC at 2000 ppm, T9 SAL at 200 ppm + ASC at 2000 ppm, T10 PUT at 15 ppm + SAL at 200 ppm + ASC at 2000 ppm 
Table 7 Influence of foliar applications with putrescine, salicylic, and ascorbic acid on peroxide value and iodine value of Picual olive oil in 2017 and 2018 seasons

\begin{tabular}{|c|c|c|c|c|c|c|c|c|c|c|c|c|}
\hline \multirow[t]{4}{*}{ Treat. } & \multicolumn{6}{|c|}{ Peroxide value (meq/kg oil) } & \multicolumn{6}{|c|}{ lodine value (mg/kg oil) } \\
\hline & \multicolumn{3}{|l|}{2017} & \multicolumn{3}{|l|}{2018} & \multicolumn{3}{|l|}{2017} & \multicolumn{3}{|l|}{2018} \\
\hline & \multicolumn{2}{|c|}{ Spraying date } & \multirow[t]{2}{*}{ Mean } & \multicolumn{2}{|c|}{ Spraying date } & \multirow[t]{2}{*}{ Mean } & \multicolumn{2}{|c|}{ Spraying date } & \multirow[t]{2}{*}{ Mean } & \multicolumn{2}{|c|}{ Spraying date } & \multirow[t]{2}{*}{ Mean } \\
\hline & Nov. & Dec. & & Nov. & Dec. & & Nov. & Dec. & & Nov. & Dec. & \\
\hline Cont. & $5.05 \mathrm{a}$ & $5.04 \mathrm{a}$ & $5.05 \mathrm{~A}$ & $5.11 \mathrm{a}$ & $5.09 \mathrm{a}$ & $5.10 \mathrm{~A}$ & $81.14 a b$ & $81.14 a b$ & $81.14 \mathrm{~J}$ & $78.57 c$ & $78.57 c$ & $78.57 \mathrm{~K}$ \\
\hline T1 & $5.00 \mathrm{ab}$ & $3.80 \mathrm{~cd}$ & $4.40 \mathrm{C}$ & $4.95 \mathrm{ab}$ & $3.87 \mathrm{~cd}$ & $4.41 \mathrm{C}$ & $82.74 a b$ & $83.37 \mathrm{ab}$ & $83.05 \mathrm{~F}$ & $83.05 b c$ & $84.33 \mathrm{abc}$ & $83.69 \mathrm{E}$ \\
\hline $\mathrm{T} 2$ & $3.72 \mathrm{~cd}$ & $3.71 \mathrm{~cd}$ & $3.71 \mathrm{H}$ & $3.61 \mathrm{~d}$ & $3.80 \mathrm{~cd}$ & $3.71 \mathrm{H}$ & $82.19 a b$ & $82.05 \mathrm{ab}$ & 82.12 I & $82.90 \mathrm{bc}$ & $81.85 b c$ & $82.37 \mathrm{H}$ \\
\hline T3 & $3.76 \mathrm{~cd}$ & $4.31 \mathrm{a}-\mathrm{d}$ & $4.03 \mathrm{E}$ & $3.81 \mathrm{~d}$ & $4.33 \mathrm{a}-\mathrm{d}$ & $4.04 \mathrm{E}$ & $85.37 a b$ & $81.58 \mathrm{ab}$ & $83.56 \mathrm{E}$ & 83.02 bc & $81.23 b c$ & $82.12 \mathrm{~J}$ \\
\hline T4 & $3.90 \mathrm{bcd}$ & $3.67 \mathrm{~cd}$ & $3.78 \mathrm{G}$ & $4.00 \mathrm{bcd}$ & $3.61 \mathrm{~d}$ & $3.80 \mathrm{~F}$ & 83.37 ab & $81.51 \mathrm{ab}$ & $82.44 \mathrm{H}$ & 82.74 bc & $85.28 \mathrm{ab}$ & $84.01 \mathrm{D}$ \\
\hline T5 & $4.66 \mathrm{abc}$ & $4.32 \mathrm{a}-\mathrm{d}$ & $4.49 \mathrm{~B}$ & $4.66 \mathrm{abc}$ & $4.33 \mathrm{a}-\mathrm{d}$ & $4.49 \mathrm{~B}$ & $85.49 a b$ & 83.66 ab & $84.57 \mathrm{C}$ & $84.85 a b$ & $86.83 a b$ & $85.84 \mathrm{~B}$ \\
\hline T6 & $3.67 \mathrm{~cd}$ & $3.73 \mathrm{~cd}$ & $3.70 \mathrm{I}$ & $3.80 \mathrm{~cd}$ & $3.75 \mathrm{~cd}$ & $3.77 \mathrm{G}$ & $80.50 \mathrm{~b}$ & 81.75 ab & $81.12 \mathrm{~K}$ & $82.40 \mathrm{bc}$ & $83.05 b c$ & $82.72 \mathrm{G}$ \\
\hline T7 & $4.19 a-d$ & $4.20 a-d$ & $4.19 \mathrm{D}$ & $4.26 a-d$ & $4.17 \mathrm{a}-\mathrm{d}$ & $4.22 \mathrm{D}$ & $86.26 \mathrm{ab}$ & $83.61 \mathrm{ab}$ & 84.93 B & $89.65 \mathrm{a}$ & $84.84 a b$ & $87.24 \mathrm{~A}$ \\
\hline T8 & $3.62 \mathrm{~cd}$ & $3.6 \mathrm{~cd}$ & $3.61 \mathrm{~K}$ & $3.70 \mathrm{~cd}$ & $3.63 d$ & $3.66 \mathrm{I}$ & $84.69 a b$ & 84.16 ab & $84.42 \mathrm{D}$ & 82.11 bc & $82.35 b c$ & 82.231 \\
\hline T9 & $3.92 \mathrm{bcd}$ & $3.36 d$ & $3.65 \mathrm{~J}$ & $3.94 \mathrm{bcd}$ & $3.48 d$ & $3.71 \mathrm{H}$ & 81.42 ab & 84.06 ab & 82.74 G & $85.22 \mathrm{ab}$ & $85.68 a b$ & $85.45 \mathrm{C}$ \\
\hline T10 & $3.96 \mathrm{a}-\mathrm{d}$ & $4.04 a-d$ & $4.00 \mathrm{~F}$ & $4.04 \mathrm{bcd}$ & $4.10 a-d$ & $4.07 \mathrm{E}$ & $87.28 \mathrm{a}$ & 84.34 ab & $85.81 \mathrm{~A}$ & $83.56 \mathrm{abc}$ & $83.66 \mathrm{abc}$ & $83.61 \mathrm{~F}$ \\
\hline Mean & $4.13 A^{*}$ & $3.98 \mathrm{~B}^{*}$ & & $4.17 A^{*}$ & $4.01 B^{*}$ & & $83.69 A^{*}$ & $82.84 B^{*}$ & & $83.46 A^{*}$ & $83.42 B^{*}$ & \\
\hline
\end{tabular}

*Mean in each column, row, or interaction with similar letter(s) are not significantly different at $5 \%$ level

T1 PUT at 15 ppm, T2 PUT at 30 ppm, T3 SAL at 200 ppm, T4 SAL at 300 ppm, T5 ASC at 2000 ppm, T6 ASC at 3000 ppm, T7 PUT at 15 ppm + SAL at 200 ppm, T8 PUT at 15 ppm + ASC at 2000 ppm, T9 SAL at 200 ppm + ASC at 2000 ppm, T10 PUT at 15 ppm + SAL at 200 ppm + ASC at 2000 ppm

and second seasons, respectively. In this manner, the control trees exhibited the highest peroxide value $(5.05$ and $5.10 \mathrm{meq} / \mathrm{kg}$ ) in the first and second seasons. As for spraying dates, results clear that spraying in November gave higher peroxide values $(4.13$ and $4.17 \mathrm{meq} / \mathrm{kg})$ as compared with spraying in December (3.98 and 4.01 $\mathrm{meq} / \mathrm{kg}$ ) in the first and second seasons, respectively. Regarding, interaction effect, trees sprayed in December with SAL at $200 \mathrm{ppm}+\mathrm{ASC}$ at $2000 \mathrm{ppm}$ (T9) recorded the minimum values (3.36 and $3.48 \mathrm{meq} / \mathrm{kg}$ ) in both studied seasons, respectively. Meanwhile, the control trees at November and December dates exhibited the maximum values in this respect in the first (5.05 and $5.04 \mathrm{meq} / \mathrm{kg}$ ) and second one (5.11 and $5.09 \mathrm{meq} / \mathrm{kg}$ ) seasons, respectively.

\section{lodine value}

Concerning iodine value, in Table 7 , results cleared that spraying different treatments led to significant increase in iodine value in both seasons. Spraying PUT at $15 \mathrm{ppm}$ $+\mathrm{SAL}$ at $200 \mathrm{ppm}+\mathrm{ASC}$ at $2000 \mathrm{ppm}(\mathrm{T} 10)$ and PUT at $15 \mathrm{ppm}+\mathrm{SAL}$ at $200 \mathrm{ppm}$ (T7) produced the highest values $(85.81$ and $87.24 \mathrm{mg} / \mathrm{kg}$ ) in the first and second seasons, respectively, while the control treatment recorded the lowest values $(81.14$ and $78.57 \mathrm{mg} / \mathrm{kg})$ in this regard in both studied seasons, respectively. As for spraying dates, November spray recorded higher values $(83.69$ and $83.46 \mathrm{mg} / \mathrm{kg}$ ) as compared with December $(82.84$ and $83.42 \mathrm{mg} / \mathrm{kg})$ in both studied seasons, respectively. Regarding interaction effect, spraying trees with PUT at $15 \mathrm{ppm}+\mathrm{SAL}$ at $200 \mathrm{ppm}+\mathrm{ASC}$ at 2000 ppm (T10) at November gave the highest value $(87.28$ $\mathrm{mg} / \mathrm{kg}$ ) in this respect in the first season, but in the second one, trees sprayed with PUT at $15 \mathrm{ppm}+\mathrm{SAL}$ at $200 \mathrm{ppm}$ (T7) at November exhibited the maximum value $(89.65 \mathrm{mg} / \mathrm{kg})$ in this regard.

\section{Discussion}

From the abovementioned results, it is clear that all treatments were able to improve all studied characters compared with the control treatment in both spraying dates of November and December in both seasons, respectively. These results agree with those obtained by Maksoud et al. (2009) who found that foliar application with ascorbic acid $1000 \mathrm{ppm}$ improved yield $\mathrm{kg} /$ tree on Chemlali olive trees. Also, foliar spraying with putrescine, ascorbic acid, and salicylic acid increased yield of Flame seedless grapevine grown under arid condition (Kassem et al. 2011). In addition, Abd El-Razek et al. (2013) cleared that foliar application with $20 \mu \mathrm{g} / \mathrm{L}$ salicylic acid at mid-February gave the highest yield of EgazyShami olive trees. Thus, Omima et al. (2014) indicated that foliar application with $3000 \mathrm{ppm}$ ascorbic acid at full bloom, 1 month later, and 1 month later after the second spray was effective in improving yield values of Manzanillo olive trees. However, Abd-El-Rhman and Attia (2016) found that maximum yield ( $\mathrm{kg} / \mathrm{tree}$ ) of 
Manzanillo olive trees verified with spraying by salicylic acid at $1000 \mathrm{ppm}$ compared with the control.

All foliar treatments in both studied date could improve physical properties of olive fruit compared with control treatments; it may be due to the role of putrescine in modulating the defense response of plants to varied environmental stresses including drought stress (Ahmed et al. 2013; Khorshidi and Hamedi 2014), as well as the ability of salicylic acid on maintaining fruit firmness, reduced chilling injury incidence, delayed membrane lipid peroxidation (Khademi and Ershadi 2013), and delayed fruit senescence through inhibiting ethylene biosynthesis which finally maintains pre- and post-harvest fruit quality (Srivastava and Dwivedi 2000). Also, ascorbic acid is considered as a natural and organic antioxidant compound (Hafez et al. 2010). It is also considered as an essential compound for plant tissues since it has antioxidant functions and acts as co-enzyme in an enzymatic cofactor and plant growth regulator (Gomez and Lajolo 2008). In addition, the positive action of antioxidants in catching or chelating the free radicals which could result in extending the shelf life of plant cells and stimulating growth aspects is reported (Rao et al. 2000). The present results regarding the influence of different foliar treatments on fruit physical properties of Picual olives in several studies are in agreement with those found by Ali et al. (2010) who cleared that fruit weight, fruit breadth, and fruit length enhanced with putrecine at $10^{-5}$ and $10^{-4} \mathrm{mM}$. Also, they observed the highest fruit properties with putrecine $10^{-4} \mathrm{mM}$ on Canino apricot trees. In addition, Abd El-Razek et al. (2013) found that application of salicylic acid at $20 \mu \mathrm{g} / \mathrm{L}$ improved fruit physical properties (i.e., fruit weight, length and diameter, seed, flesh, and fruit dry weight) and fruit oil content of EgazyShami olive trees. In other investigation on Amhat date palm, Abd El-Migeed et al. (2013) found that foliar spraying with putrescine at $0.45 \mathrm{mM}$ treatments gave the highest flesh weight, fruit length, and diameter and pulp/seed ratio. Also, on Manzanillo olive trees, Omima et al. (2014) reported that spraying with ascorbic acid gave the highest fruit quality compared with other treatments and (Ahmed et al. 2011) on grapevines. In this manner, on mango trees, Hanan (2015) showed that spraying with ascorbic acid at $1 \mathrm{Mm}+$ salicylic acid at $2 \mathrm{Mm}$ presented the highest fruit weight, thickness, and pulp percentage.

As a result of the role of the foliar spraying to improve fruit yield and physical parameters, the oil yield also was improved as a consequence to that. The previous results are in harmony with Maksoud et al. (2009) who showed that spraying with ascorbic acid $1000 \mathrm{ppm}$ on the 1st of April, May, and June combined with soil application of phosphorine increased the flesh oil content of Chemlali olive trees compared with other treatments. Additionally, Abd El-Razek et al. (2013) found that application of salicylic acid at $20 \mu \mathrm{g} / \mathrm{L}$ improved fruit oil content of EgazyShami olive trees. Therefore, Abd-El-Rhman and Attia (2016) clearly showed that foliar spraying with salicylic acid at $1000 \mathrm{ppm}$ led to improving the flesh oil content percentage of Manzanillo olive fruits. In the same respect, Brito et al. (2018) mentioned that flesh oil content increased in the first year and decreased in the second one with salicylic acid at $100 \mu \mathrm{M}$ on olive trees.

Chemical properties of fruit oil in this study were improved as a result of foliar spraying compared with control treatment. These observations are in accordance with those obtained by Malik and Singh (2006) who showed that application with putrescine at $0.1 \mathrm{mM}$ decreased acidity of fruit juice, while Abd-El-Rhman and Attia (2016) clearly showed that foliar spraying by salicylic acid at $1000 \mathrm{ppm}$ led to reduction total acidity percentage of Manzanillo olive fruits. On the other hand, these results disagree with Brito et al. (2018) who mentioned that foliar sprays with salicylic acid did not significantly affect the olive oil properties such as oil acidity percentage and peroxide value of olive oil.

\section{Conclusion}

Spraying Picual olive trees with putrescine and salicylic and ascorbic acid in this study under the conditions of the saline irrigation water $\left(4.40 \mathrm{ds} \mathrm{m}^{-1}\right)$ was able to improve fruit yield and fruit physical and chemical properties of olive trees of Picual cv. compared with the control treatment in both spraying dates of November and December in both seasons, respectively. Moreover, the best yield of olive fruits in this study was recorded with the application of putrescine at $15 \mathrm{ppm}+$ salicylic at $200 \mathrm{ppm}+$ ascorbic at $2000 \mathrm{ppm}$ in the first and second seasons, respectively.

\section{Abbreviation}

SAL: Salicylic acid; ASC: Ascorbic acid; PUT: Putrescine

\section{Acknowledgements}

The authors are grateful and thankful to both of the National Research Center and Faculty of Agriculture, Ain Shams University, for their efforts

\section{Significance statement}

The study represented useful treatments to increase the quality and quantity of olive fruits and oil yields under the condition of salinity

\section{Authors' contributions}

EAEG contributed to the design and performance of the experiment and also to the data analysis, writing of the manuscript, and following up the publication with the journal (correspondence). NAA contributed to the design and performance of the experiment and also to the data analysis and writing of the manuscript. HSAH contributed to the design and performance of the experiment and also to the data analysis and writing of the manuscript. AMH contributed to the design and performance of the experiment and also to the data analysis and writing of the manuscript. LFH contributed to the design and performance of the experiment and also to 
the data analysis and writing of the manuscript. All authors read and approved the final version.

\section{Funding}

This work does not have any funding support

\section{Availability of data and materials}

All data generated or analyzed during this study already exist in this published article.

\section{Ethics approval and consent to participate}

Not applicable

\section{Consent for publication}

Not applicable

\section{Competing interests}

The authors declare that they have no competing interests.

\section{Author details}

${ }^{1}$ Pomology Department, National Research Centre, 33 El Bohouth St, Cairo 12622, Egypt. ${ }^{2}$ Horticulture Department, Faculty of Agriculture, Ain Shams University, P.O. Box 68, Hadayek Shoubra, Cairo 11241, Egypt.

Received: 13 March 2020 Accepted: 4 May 2020

Published online: 03 June 2020

\section{References}

Abd El-Migeed MMM, Mostafa EAM, Ashour NE, Hassan HSA, Dorria MM, Saleh MMS (2013) Effect of potassium and polyamine sprays on fruit set, fruit retention, yield and fruit quality of Amhat date palm. Int J Agric Res 8:77-86

Abd El-Razek E, Hassan HAS, Karima MGE (2013) Effect of foliar application with salicylic acid, benzyladenine and gibberellic acid on flowering, yield and fruit quality of olive trees (Olea europaea L.). Middle-East J Sci Res, 1406 14(11):1401

Abd-El-Rhman IE, Attia MF (2016) Foliar spray with potassium nitrate and salicylic acid for improving growth, yield and nutrients uptake by olive trees under salinity stress conditions. Int J ChemTech Rese 9(12):230-245

Ahmed AHH, Darwish E, Alobaidy MG (2017) Impact of putrescine and 24epibrassinolide on growth, yield and chemical constituents of cotton (Gossypium barbadense L.) plant grown under drought stress conditions. Asian J Plant Sci 16(1):9-23

Ahmed AHH, Darwish E, Hamoda SAF, Alobaidy MG (2013) Effect of putrescine and humic acid on growth, yield and chemical composition of cotton plants grown under saline soil conditions. Am-Euras J Agric Environ Sci 13(4):479-497

Ahmed FF, Abdel-Aal AMK, Abdelaziz FH, El-Kady-Hanaa FM (2011) Productive capacity of Thompson seedless grapevines as influenced by application of some antioxidants and nutrient treatments. Minia J Agric Res Develop 31(2): 219-232

Ali EA, Sarruy SMA, Hassan HSA (2010) Improving Canino apricot trees productivity by foliar spraying with polyamines. J Appl Sci Res 6(9):1359-1365

Arfan M, Athar HR, Ashraf M (2007) Does exogenous application of salicylic acid through the rooting medium modulate growth and photosynthetic capacity in two differently adapted spring wheat cultivars under salt stress. J Plant Physiol 164:685

Athar H, Khan A, Ashraf M (2008) Exogenously applied ascorbic acid alleviates salt induced oxidative stress in wheat. Environ Exp Bot 63:224-231

Atta-ur-Rahman BA (1990) Studies in natural products chemistry, vol 32. Elsevier Science, Amsterdam

Banat F, Pal P, Jwaied N, Al-Rabadi A (2013) Extraction of olive oil from olive cake using soxhlet apparatus. Am J Oil Chem Tech 4(1):2326-6570

Bracci T, Busconi M, Fogher C, Sebastiani L (2011) Molecular studies in olive (Olea europaea L.): overview on DNA markers applications and recent advances in genome analysis. Plant Cell Rep 30(4):449-462. https://doi.org/10.1007/ s00299-010-0991-9

Brito C, Dinis L, Silva E, Gonçalves A, Matos C, Rodrigues MA, Moutinho-Pereiraa J, Barros A, Correia C (2018) Kaolin and salicylic acid foliar application modulate yield, quality and phytochemical composition of olive pulp and oil from rainfed trees. Sci Hortic 237:176-183

Dieffenbacker A. and W. D. Pocklington, (1992). Standard methods for analysis of oils, fats and derivatives. Oxford Blackwell scientific puplications, London, UK, $1^{\text {st }}$ supplement to the $7^{\text {th }}$ edition, pp 1-151.
Duncan DB (1955) Multiple ranges and multiple tests. Biometrics 11:1-24

Foyer CH, Noctor G (2011) Ascorbate and glutathione: the heart of the redox hub. Plant Physiol 155:2-18

Gomez ML, Lajolo FM (2008) Ascorbic acid metabolism in fruits: activity of enzymes involved in synthesis and degradation during ripening in mango and guava. J Sci Food Agric 88:756-762

Grohmann F (1981) Oleaceae. Flora Pakistan 59:9

Gunstone FD (2002) Vegetable oils in food technology: composition, properties and uses. Book published by Blackwell Publishing Ltd

Hafez OM, Hamouda HA, Abd El-Mageed MA (2010) Effect of calcium and some antioxidants treatments on storability of Le Conte pear fruits and its volatile components. Nat Sci 8(5):109-126

Hanan AMRE (2015) Effect of ascorbic and salicylic acid on leaf area, n, p, k content as well as yield and its components of mango (Mangifera indica l.) Trees. J Plant Production, Mansoura Univ 6(10):1619-1629

Jacobs MB (1959) The chemical analysis of food and products. D.Van. Nostrand Company, Inc, New York, pp 380-381

Kaniewski D, van Campo E, Boiy T, Terral J-F, Khadari B, Besnard G (2012) Primary domestication and early uses of the emblematic olive tree: palaeobotanical, historical and molecular evidence from the Middle East. Biol Rev 87(4):885899. https://doi.org/10.1111/j.1469-185x.2012.00229.x

Kassem HA, Al-Obeed RS, Soliman SS (2011) Improving yield, quality and profitability of flame seedless grapevine grown under arid environmental by growth regulators preharvest applications. Middle-East J Sci Res 8(1):165-172

Khademi Z, Ershadi A (2013) Postharvest application of salicylic acid improves storability of peach (Prunus persicacv Elberta) fruits. Int J Agric Crop Sci 5: $651-655$

Khan MIR, Fatma M, Per TS, Anjum NA, Khan NA (2015) Salicylic acid-induced abiotic stress tolerance and underlying mechanisms in plants. Front Plant Sci 6:462

Khan MIR, Syeed S, Nazar R, Anjum NA (2012) An insight into the role of salicylic acid and jasmonic acid in salt stress tolerance. In: Khan NA, Nazar R, labal N, Anjum NA (eds) Phytohormones and Abiotic Stress Tolerance in Plants. Springer, Berlin, pp 277-300

Khorshidi M, Hamedi F (2014) Effect of putrescine on lemon balm under salt stress. Intl J Agri Crop Sci 7(9):601-609

Kiritsakis A (1998) Olive oil-Second Edition, From the tree to the table. Food and Nutrition. Press, Inc., Trumbull, Connecticut, p 006611

Li Z, Zhang Y, Peng D, Wang X, Peng Y, He X, Zhang X, Ma X, Huang L, Yanhong $Y$ (2015) Polyamine regulates tolerance to water stress in leaves of white clover associated with antioxidants defense and hydringenes via involvement in calcium messenger system and hydrogen peroxide signaling. Front Physiol 280(6):16

Maksoud MA, Malaka AS, El-Shamma MS, Amera AF (2009) The beneficial effect of biofertilizers and antioxidants on olive trees under calcareous soil conditions. World J Agric Sci 5(3):350-352

Malik AU, Singh Z (2006) Improved fruit retention, yield and fruit quality in mango with exogenous application of polyamines. ScientiaHorticulturae 110(2):167-174

Naz H, Akram NA, Ashraf M (2016) Impact of ascorbic acid on growth and some physiological attributes of cucumber (Cucumis sativus) plants under waterdeficit conditions. Pak J Bot 48:877-883

Noctor G, Mhamdi A, Foyer CH (2014) The roles of reactive oxygen metabolism in drought: not so cut and dried. Plant Physiol 164:1636-1648

Omima ME, El-Gammal OHM, Salama ASM (2014) Effect of ascorbic acid, proline and jasmonic acid foliar spraying on fruit set and yield of Manzanillo olive trees under salt stress. Scientia Hort 176:32-37

Pérez JA, Hernández JM, Trujillo JM, López H (2005) Iridoids and secoiridoids from Oleaceae. Stud Nat Prod Chem 32:303-363. https://doi.org/10.1016/ s1572-5995(05)80059-6

Rao MV, Koch R, Davis KR (2000) Ozone a tool for probing programmed cell death in plants. Plant Mol Biol 44(3):346-358

Sarwar M (2013) The theatrical usefulness of olive Olea europaea L.(Oleaceae family) nutrition in human health: a review. Sky J Med Plant Res 2(1):1-4

Snedecor GW, Cochran WD (1980) Statistical methods, 7th edn. the lowa State University Press, Ames, p 491

Soni MG, Burdock GA, Christian MS, Bitler CM, Crea R (2006) Safety assessment of aqueous olive pulp extract as an antioxidantor antimicrobial agent in foods. Food Chem Toxicol 44:903-915

Srivastava MK, Dwivedi UN (2000) Delayed ripening of banana fruit by salicylic acid. Plant Sci 158:87-96 
Wild SA, Corey RB, Lyer JG, Voigt GK (1985) Soil and plant analysis for tree culture. Oxford and IBH Publishing Co., New Delhi

Zohary D, Hopf M, Weiss E (2012) Domestication of plants in the old world: the origin and spread of domesticated plants in Southwest Asia, Europe, and the Mediterranean Basin. Oxford University Press, Oxford

\section{Publisher's Note}

Springer Nature remains neutral with regard to jurisdictional claims in published maps and institutional affiliations.

Submit your manuscript to a SpringerOpen ${ }^{\odot}$ journal and benefit from:

- Convenient online submission

- Rigorous peer review

- Open access: articles freely available online

- High visibility within the field

- Retaining the copyright to your article

Submit your next manuscript at $\boldsymbol{\nabla}$ springeropen.com 